\title{
Evaluation of innovation activities and innovation management model of selected innovative companies
}

\author{
Jindra Peterková1,*, Katarzyna Czerná ${ }^{2}$, and Pavla Macurová ${ }^{3}$ \\ ${ }^{1}$ Faculty of Economics, VSB - Technical University of Ostrava, Department of Business \\ Administration, Czech Republic \\ ${ }^{2}$ Faculty of Economics, VSB - Technical University of Ostrava, Department of Business \\ Administration, Czech Republic \\ ${ }^{3}$ Faculty of Economics, VSB - Technical University of Ostrava, Department of Business \\ Administration, Czech Republic
}

\begin{abstract}
The company's success lies in understanding its situation and the differences in its own business and in creating original, and functioning innovation management system. The main task of the owner and management of the company is to create conditions for the creativity of its employees through the created method of providing financial resources and systematic creation of the research team. Innovation and its successful management and implementation helps to overcome the challenges of globalization. The paper aims to evaluate innovation activities, especially concerning the type of implemented innovation activities, initiator, way of development, obstacles, and type of protection of intellectual property. At the same time, the evaluation of innovation activity management is carried out according to the model of Wolcott and Lippitz (2007), which takes into account two parameters, namely the power of authority and organizational responsibility. Data on innovation activities of enterprises are obtained through a proper questionnaire survey carried out by selected innovative companies. The results of the questionnaire survey are evaluated using the IBM SPSS Statistics 21 statistical program. Cluster analysis is also used to identify categories of innovative enterprises.
\end{abstract}

\section{Introduction}

At a time when change is the only constant in the business world, innovation plays a vital role for businesses and entrepreneurs. Innovation and its approach to their management and implementation are a prerequisite for a successful business in a highly competitive business environment.

Innovation activities according to the Oslo Manual (2005) relate to the improvement and improvement of products and services, production processes and are associated with the use of new promotional means for products and services or linked to the introduction of new organizational changes to enhance the process efficiency within the company.

\footnotetext{
* Corresponding author: jindra.peterkova@vsb.cz
} 
According to the methodology of Eurostat (2010), innovative enterprises are enterprises that have introduced any of the following innovations during the period: product, process, marketing, and organizational.

Evaluation of innovation activities is carried out in EU countries by statistical authorities in individual countries through a statistical sample survey in two-year cycles. The results of the last innovation survey are for the period 2014-2016. The basis for the collection of data on business innovation activities is the harmonized Eurostat model questionnaire on the EU CIS 2016 (Community Innovation Survey 2016). The disadvantage of the results obtained from the statistical survey is the anonymity of the data for further analysis of the innovation process. A more detailed understanding of the challenges involved in managing the innovation process requires personal inquiry.

The paper aims to evaluate innovative activities concerning selected criteria in selected innovative enterprises in the Czech Republic and Poland, specifically focusing on innovative enterprises in the Moravian-Silesian Region and Silesian Voivodeship. The selection of these two border regions is made concerning their similar economic and cultural development, and the conditions for the implementation and management of innovative activities are identical. The comparison of the two regions will enable us to obtain information on possible differences in the evaluation of innovation activities and management of the innovation process. The assessment is carried out through a questionnaire survey on a research sample of 80 innovative enterprises. At the same time, the innovation management evaluation of innovative enterprises is carried out based on the Wolcott and Lippitz model. Cluster analysis, ward method with Euclidean distance is used to compare the results from the evaluation of innovation activities and their management for the Czech Republic and Poland.

\section{Theoretical Background}

\subsection{The contemporary state of knowledge in literature}

Given the growing competition, the isolated focus on process efficiency management, cost reduction, or product quality loss is no longer critical. On the contrary, the importance of comprehensive management and implementation of innovative activities is growing [1-4].

Authors $[2,3,5,6]$ point out that the established innovation management system plays an essential role in the creation and implementation of innovations in the company. Innovation management represents a complex of activities connected with the initiation of changes up to their application [2]. At the same time other emphasize that innovation management should be accompanied by building an organization that can learn and innovates [7-12]. Given the crucial role of innovation in business, new strategies, approaches, or models are emerging to support the management of innovation activities.

One approach is the "New game strategy," which it describes as a set of new activities that create or add value to the customer, in particular by reworking the events carried out within the value chain [13]. It is also emphasized that companies can now benefit from experience from external suppliers and an external knowledge base [14-17]. They recommend implementing an open innovation strategy. At the same time, such innovation implementation management helps to overcome the challenges of globalizing the business environment.

The Wolcott and Lippitz matrices define how to initiate an internal business that generates new use of market opportunities. It is a new type of internal business approach, whereby the company management and its owners create conditions for the creativity of their employees. It is based on a matrix of four main models of innovative internal entrepreneurship concerning organizational responsibility and resource authority [18]. 
Source power is considered to be an ex-post or ex-ante approach to the provision of funds. The ex-post approach to funding is based on funding only after evaluating the value of the projects.

In contrast, the ex-ante approach is based on the systematic provision of funds before the implementation of innovative activities. Organizational responsibility means organizing employees implementing innovative projects, which has a concentrated form, i.e., teams are created or scattered, ie. Individual employees have no background. With this in mind, companies apply an innovation management model:

producer - there is the support of the established research team for the whole enterprise and its systematic financial assistance,

enabler - implementation of innovative projects is scattered, only selected projects are supported, and they are systematically financially supported,

advocate- there is support for the concentrated implementation of innovative activities within separate business units to which funds are allocated,

opportunist- there is no intentional focus on innovation activity, and also the funds are not systematic, but are assigned only after assessing the suitability of the innovation project (shown in Figure 1).

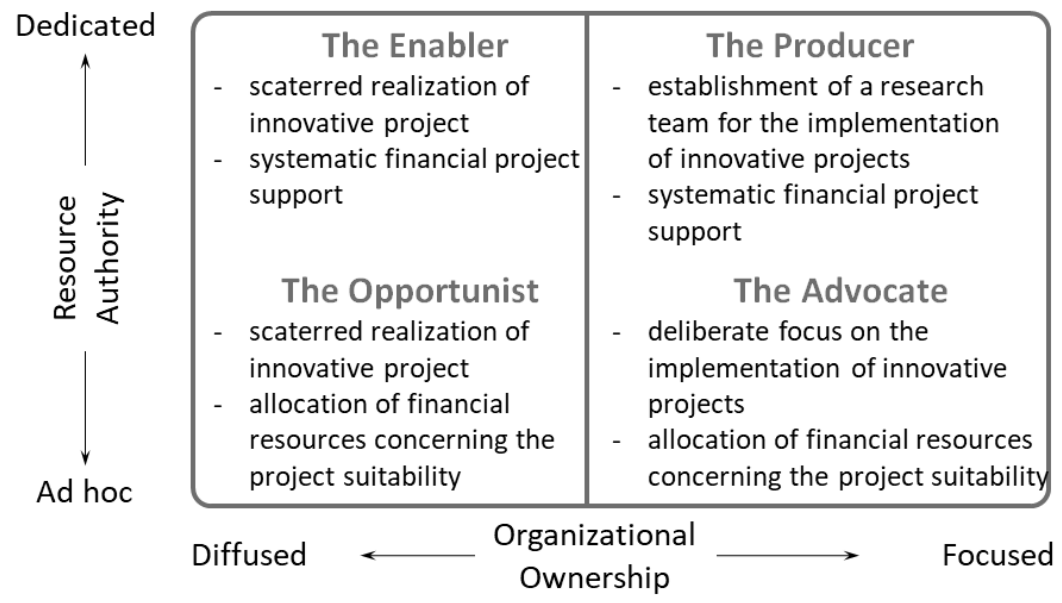

Fig. 1. Models of innovative business (Wolcott \& Lippitz, 2007)

Verifying this model in practice makes it possible to ascertain the systematic implementation of innovation activities concerning the allocation of funds and about the conditions created for the application of innovation.

\subsection{Methodology}

For evaluation of the innovation activities of innovative enterprises in the MoravianSilesian Region and the Silesian Voivodeship, a questionnaire survey is carried out, and then a cluster analysis is carried out to compare the results obtained.

The questionnaire survey was carried out based on the created questionnaire and was carried out from June 1 to June 30, 2019. The survey contains open, closed, and evaluation questions. The research sample consisted of 80 innovative enterprises. Of which 40 innovators in the Moravian-Silesian Region and 40 innovators in the Silesian Voivodeship. Innovative enterprises in the Czech Republic and Poland were selected from the AIP database (Association of Innovative Entrepreneurship). The companies were contacted by telephone, and subsequently, a questionnaire was sent on-line by e-mail. The questionnaire 
was explained and filled in. The questionnaire addressed the executive director or the director of research and development in the company.

Within the research, the following hypotheses were defined:

H1: There is a link between innovation and business philosophy of innovative enterprises in the Moravian-Silesian Region and Silesian Voivodeship

$\mathrm{H} 2$ : There is a correlation between the size of the business and the type of innovation management model.

Cluster analysis [19-20] is applied to analyze multidimensional data to categorize a plurality of objects into several relatively homogeneous subsets, referred to as clusters. Objects within clusters should be as similar as possible and objects belonging to different clusters as different as possible. The essential criterion for creating object clusters is the similarity between objects. Similarity measurements can be made using an appropriate measure of correlation, the measure of distance, or measure of association. Correlation and distance measures are mainly used for ratio data, while association measures are intended instead for enumeration (nominal) data. Standard distance measures include Euclidean Distance, Euclidean Distance Square, Manhattan Distance (Hamming Metric), Generalized Minkovski Metric, Chord Distance, and Mahalanobis Metric. Conventional clustering methods include: nearest neighbor method - the clustering pair is selected according to the smallest distance; furthest neighbor method - the clustering pair is chosen according to the most considerable range; average distance method - based on the average length of all objects in cluster 1 to all objects in cluster 2 and Ward's method - in each step the increment of sum of squares of deviations resulting from their merging is calculated, and then the clusters are joined together which corresponds to the minimum value of this increment. Clustering by this method can be represented using a binary tree, a dendrogram.

\section{Obtained results}

The evaluation of innovation activities of innovative enterprises in the Moravian-Silesian Region and the Silesian Voivodeship was carried out based on selected criteria, mainly based on the type of implemented innovation activities, initiator of innovation activities, development of innovative products and processes, obstacles and intellectual property protection. At the same time, the way of innovation management was evaluated.

Innovations are part of the corporate philosophy of most innovative enterprises, both in MSK (90.9\%) and in Silesian Voivodeship (60\%). The hypothesis H1, whether there is a relationship between innovation and business philosophy $(0,049<0.05)$, was verified.

In innovation enterprises, both in the Moravian-Silesian Region and in the Silesian Voivodeship, technical innovations (product and process) are most implemented before non-technical innovations (marketing and organizational). Of the technological innovations, product innovation is the most achieved (66\% in the Czech Republic, $72 \%$ in Poland), followed by process innovation (39\% in the Czech Republic, $37 \%$ in Poland). Out of nontechnical innovations, organizational innovation (16\% in the Czech Republic, $18 \%$ in Poland) and marketing innovations (14\% in the Czech Republic, $12 \%$ in Poland) are the most implemented.

It is interesting to note that management (56\%) and not the owner $(50 \%)$ are the main initiators of innovation activities in MSR and Silesian Voivodeship enterprises while the significant influence of management as the initiator of innovation activities $(65 \%)$ than the owner (32\%) is seen in the Silesian Voivodeship.

Innovated products and processes are developed by enterprises in the Moravian-Silesian Region, mainly in their R\&D department (72.7\%) and in cooperation with universities (40.9\%). The situation is different for enterprises in Silesian Voivodeship, where innovated products and processes are developed primarily in collaboration with research institutions 
$(42,5 \%)$ and enterprises outside the corporate group $(42,5 \%)$, then in cooperation with universities (40\%).

Differing results result from a significantly smaller number of $R \& D$ departments in enterprises in Silesian Voivodeship. The lack of skilled labor $(61.4 \%)$ and financial resources $(50 \%)$ are among the main obstacles to the implementation of innovative activities in MSR enterprises. For enterprises in the Silesian Voivodeship, the main obstacles are lack of funds $(87,5 \%)$ and low or uncertain return on investment due to low purchasing power or market size $(75 \%)$.

To evaluate innovation management, a matrix of four models was applied as part of the research: opportunist, enabler, producer, and advocate. Although these are innovative enterprises in both selected regions, a large part of enterprises does not apply any model of innovation management (43.2\% - MSR, 37.5\% - Silesian Voivodeship). This means that in managing innovation, it does not emphasize the systematic support for the implementation of innovative projects and, at the same time, funds are not systematically allocated. At the same time, it was found that the majority of companies in MSR apply the advocate model $(18.2 \%)$, ie, intentional focus on the implementation of innovative projects, but the allocation of funds is according to the suitability of the project. In the Silesian Voivodeship, enterprises apply the occasional model $(47.5 \%)$, ie, scattered implementation of innovative projects and allocation of funds according to project suitability. At the same time, the hypothesis $\mathrm{H} 2$, whether there is a relationship between the size of the company and the model of innovation management $(0,049<0.05)$, was verified. The results are shown in Figure 2.

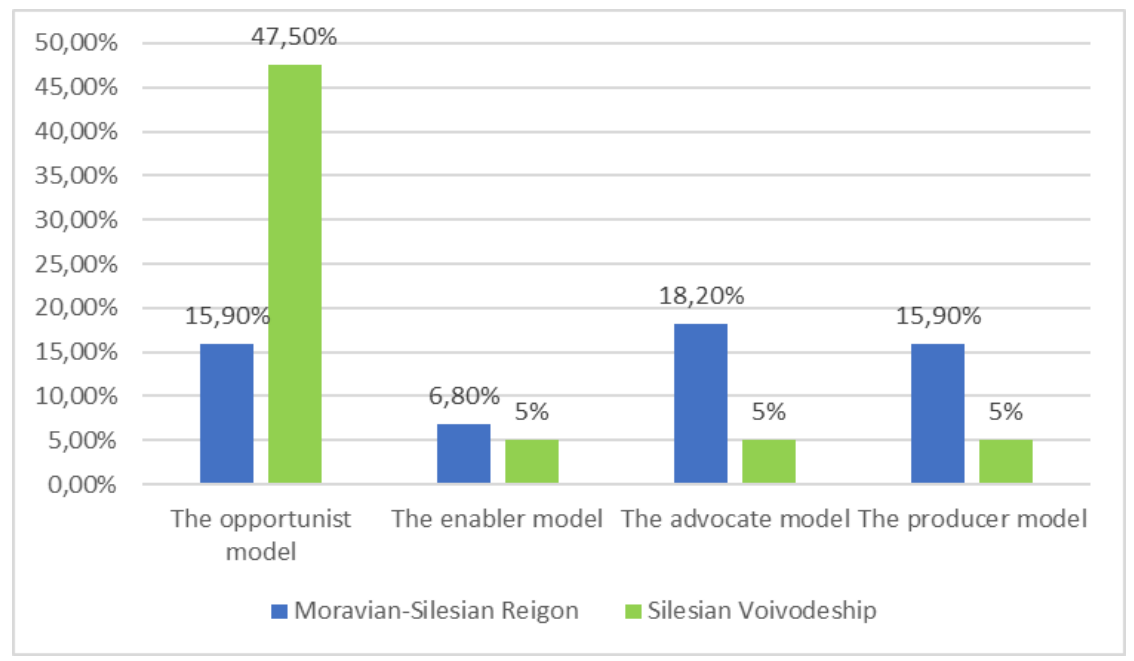

Fig. 2. Models of innovative business

Innovative enterprises in the Moravian-Silesian Region and the Silesian Voivodeship make use of entirely different means of protecting intellectual property. Innovative enterprises in the Moravian-Silesian Region make the most use of legal protection in the form of trademark registration (40.9\%), utility model application (36.4\%) and trade secrets $(31.4 \%)$ and patent applications $(31.8 \%)$ the same level. In terms of legal protection, innovative enterprises in Silesian Voivodeship make the most use of trade secrets $(85 \%)$, industrial design applications (42.5\%) and utility models (30\%). 


\section{Conclusion and Discussion}

Although both regions are economically and culturally similar, differences are found in the way they develop innovative products and processes, barriers and in applied innovation management models. In contrast, in both regions, innovation plays an essential role in business philosophy. At the same time, mainly technical and product innovations are realized.

Concerning the observed differences in the implementation and management of innovations, a cluster analysis is performed using the Ward method with Euclidean distance. Within the cluster analysis, 80 enterprises (40 CR + 40 PL) were evaluated based on six criteria: sales, $R \& D$, company size, innovation management model, innovation as part of the corporate philosophy and type of innovation.

Based on the application of the Ward method with Euclidean distance, 12 clusters were created, of which only 8 of them are significant for evaluation. The results show Figure 2. An essential criterion of similarity in cluster 1 is competition as a result of innovation activity, in cluster 2 it is its R\&D workplace, in cluster 3 formalization of innovation implementation steps, in cluster 4 investing in innovation up to $15 \%$ profit, cluster 5 showed similarity in the existing formalization of the innovation process, cluster 6 was a low investment of knowledge (10\%), cluster 7 had the similarity criterion as revenue from innovation of $15 \%$, and in 8 only product innovation.

Individual cluster groupings pointed to differences between selected regions, especially in the area of existence of own research and development (in PL it is $50 \%, 68,2 \%$ in the $\mathrm{CZ}$ ), also in the size of the company, the difference is also in the results (in Poland the result is mainly the increase of competitiveness, in the Czech Republic the improvement of the quality of the product or service compared to the competition).

If we also use the NACE classification for categorization, the clusters are further sorted according to the field, and it was found that the specifics have companies both in the $\mathrm{CZ}$ and PL in the area of information and communication activities where research and development exist, although they do not have individual steps defined. Innovation process and innovation are an essential part of corporate philosophy. For manufacturing companies, the innovation process is formalized, and innovations are implemented to increase competitiveness.

At the same time, the cluster analysis found out the influence of the size of the company on the implemented model of innovation management. It turned out that large companies (over 250 employees) apply the production model, while other companies either have an occasional model or even no model.

In light of the results, it appears that further research should focus on the implementation of the innovation process, including related problems. 
Table 1. Setting Word's margins

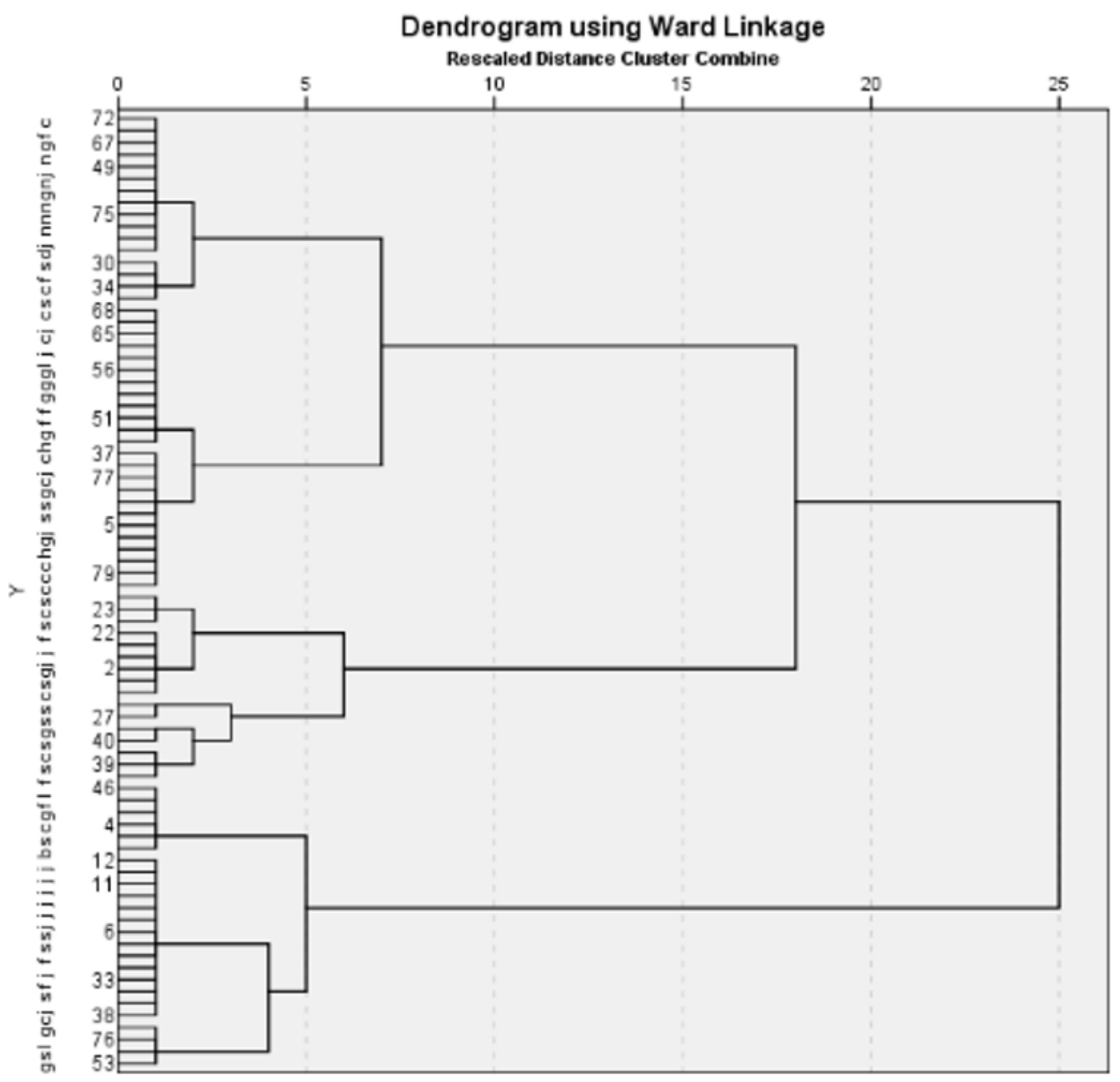

\section{References}

1. J. Tidd, J. Bessant, K. Pavitt, Managing Innovation: Integrating Technological, Market and Organizational Change (Chichester: Wiley, 2013).

2. J. Veber, et al., Management inovaci (Praha: Management Press, 2016).

3. J. Peterková, Využití konceptů inovací v průmyslovém podniku (Ostrava: VŠB - TUO, 2018).

4. P. A. Gupta, B. T. Trusko, Global Innovation Science Hanbook (USA: McGraw-Hill Education, 2014).

5. T. Krasnicka, W. Glod, M. Wronka-Pospiech, Management innovation, proinnovation organisational culture and enterprise performance: testing the mediation effect. Review of managerial science, 12, 3 (2018)

6. J. Birkinshaw, G. Hamel, M. J. Mol, Management innovation. Academy of Management Review, 33, 4 (2008)

7. J. Košturiak', J. Chal', Inovace vaše konkurenční výhoda! (Brno: Computer Press, 2008). 
8. T. da Silva Lopes, M. Casson, G. Jones, Organizational innovation in the multinational enterprise: Internalization theory and business history. Journal of International Business Studies, 50, 8 (2019)

9. E. Cefis, O. Marsili, D. Rigamoti, In and Out of Balance: Industry Relatedness, Learning Capabilities and Post-Acquisition Innovative Performance. Journal of Management Studies, (2019)

10. A. Sagasta, Cooperative R\&D with durable goods. Journal of Economics, (2019)

11. M. Nippa, J. Reuer, On the future of international joint venture research. Journal of International Business Studies, 50, 4

12. J. Zhang, H. Jiang, R. Wu, J. Li, Reconciling the Dilemma of Knowledge Sharing: A Network Pluralism Framework of Firms' R\&D Alliance Network and Innovation Performance. Journal of Management. (2018)

13. A. Afuah, Strategic Innovation. New game strategies for competitive Advantage (New York: Routledge, 2009).

14. H. Chesbrough, Open Innovation - The New Imperative for Creating and Profiting from Technology (Boston: Harvard Business School Publishing, 2003).

15. P. Herzog, Open and Closed Innovation (Wiesbaden: Gabler Verlag, 2011).

16. E. Tarraço, R. Bernardes, F. Borini, D. Rossetto, Innovation capabilities for global R\&D projects in subsidiaries. European Journal of Innovation Management, 22, 4 (2019)

17. X. Zhu, Z. Xao, M. C. Dong, J. Gu, The fit between firms' open innovation and business model for new product development speed: A contingent perspective. Technovation, 86-87 (2019)

18. R. C. Wolcott, M. Lippitz, The Four Models of Corporate. Entrepreneurship. MIT Sloan Management Review 49, 1 (2007)

19. K. Charry, K. Coussement, N. Demoulin, N. Heuvinck, The Ward's minimum variance method is the most commonly used method in management. In: Marketing Research with IBM SPSS Statistics. (New York: Routledge, 2016).

20. H. Řezanková, D. Húsek, V. Snášel, Shluková analýza dat (Praha: Professional Publishing, 2009). 